\title{
Die Scham
}

Beiträge zur Physiologie, zur Psychologie und zur Soziologie des Schamgefühls

\section{Adolf Gerson}

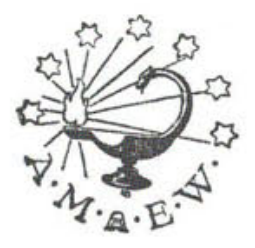

BONN 1919

A. Marcus \& E. Webers Verlag (Dr. jur. Albert Ahn) 